YEARBOOK
of ANTITRUST
and REGULATORY
STUDIES
www.yars.wz.uw.edu.pl

\author{
Peer-reviewed scientific periodical, \\ focusing on legal and economics \\ issues of antitrust and regulation. \\ Creative Commons Attribution-No \\ Derivative Works 3.0 Poland License
}

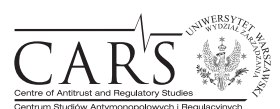

Centre of Antitrust and Regulatory Studies, University of Warsaw, Faculty of Management www.wZ.uw.edu.pl

\title{
Wide scope of administrative discretion justified by features of telecommunications market. \\ Case comment to the judgment of the Polish Supreme Court \\ of 2 April 2009 - Telekomunikacja Polska SA v the President \\ of the Electronic Communications Office \\ (Ref. No. III SK 28/08)
}

Facts

On 2 April 2009, the Polish Supreme Court (hereafter, Supreme Court or Court) delivered a judgment on the scope of power of the President of the Electronic Communications Office (hereafter, UKE) to impose obligations upon telecommunications operators in respect to particular markets under the Polish Telecommunications Law of 16 July 2004 (hereafter, PT) ${ }^{1}$, and Directive 2002/21/EC (hereafter, Framework Directive $)^{2}$. The Supreme Court rejected all claims of the plaintiff, Telekomunikacja Polska SA (hereafter, TP SA), against the UKE President decision (hereafter, Decision).

In her Decision the UKE President stated that no effective competition exists on the national market for call origination services in the fixed line public telephone network. Hence, the plaintiff was defined as an undertaking having significant market power (SMP) on the national market for provision of call origination services on a fixed line public telephone network. Consequently, the UKE President imposed several regulatory duties upon the plaintiff such as:

1. Obligation to accept justified applications by other telecom undertakings to provide them telecommunications access, including the use of network elements and associated facilities aimed at access and call origination provision on a fixed line public telephone network by:

a) ensuring the possibility of service management for end-users by entitled telecoms undertakings service provision on their behalf;

b) ensuring specific elements of telecommunications networks, including lines and connections;

\footnotetext{
1 Act of 16 July 2004 - Telecommunications Law (Journal of Laws 2004 No. 171, item 1800, as amended).

2 Directive 2002/21/EC of the European Parliament and of the Council on a common regulatory framework for electronic communications networks and services, OJ [2002] L 108/33.
} 
c) offering of services on a wholesale basis for their resale by another undertaking;

d) granting access to interfaces, protocols or other key technologies necessary for network inter-operability, including virtual networks;

e) ensuring telecommunications infrastructure, collocation and other forms of common usage of buildings;

f) ensuring the functioning of networks necessary for full service interoperability, including service provision in intelligence networks;

g) ensuring systems that support operational activity or other software systems indispensable for effective competition, including price lists, billing systems and debt collection;

h) ensuring network connections, telecom appliances and associated facilities;

i) conducted negotiations on telecommunication access in good faith and maintaining previously established access to specific telecom networks, appliances and associated facilities, as well as through every other form of assured usage of telecom appliances and associated facilities provided in the form of minutes or capacity for the provision of access and call origination service on a fixed line public telephone network (Article 34 PT).

2. Obligation to treat telecom undertakings equally in respect to telecommunications access for the provision of access and call origination on a fixed line public telephone network, in particular, by offering equal conditions in comparable situations as well as by offering services and disclosing information on conditions not worse than those applied within its own enterprise or in relations with dependent entities (Article 36 of PT).

3. Obligation to publish information on telecommunications access and information on technical networks and appliance specifications, network features, terms and conditions of service provision and usage of a network and fees (Article 37 of PT).

4. Obligation to conduct regulatory accounting in a manner allowing identification of internal transfers linked to telecommunications access activity (Article 49-54 of PT).

5. Obligation to calculate the justified cost of telecommunications access according to a method of future orientated long-term incremental costs that accords with a description of cost calculation accepted by the UKE President; application of telecommunications fees that account for recovery of justified operator costs (Article 39 PT).

6. Obligation to set access fees on the basis of costs incurred until posting of the cost calculation together with an auditor's opinion on the accuracy of such calculation (Article 40 PT).

7. Obligation to prepare and present a framework offer on access that meets all obligations set forth in Annex no. 1 to the Decision within three months from the Decision date. The number and location of access spots must consider justified applications of all telecom operators who wish to connect to the plaintiff's 
network. The plaintiff shall propose at least existing spots of inter-network connections (Article $42 \mathrm{PT}$ ).

In its claim, TP SA submitted various infringements such as: abuse of powers by the UKE President who failed to respect requirements of proportionality and adequacy of obligation imposed upon an identified aim (Article 25(4) PT). Secondly, according to the plaintiff, the imposition of a regulatory obligation aimed at solving competition problems on the retail market was not legally grounded since the powers vested in the UKE President only apply toward the wholesale market. Thirdly, TP SA submitted that the UKE President infringed art. 40 PT by imposing different methods than the comparative method indicated in Article 40(3) PT.

Another TP SA claim concerned infringement by the UKE President of art. 42(4) PT in connection with $\S 3$ of the regulation on the framework offer through his erroneous application of these provisions such that the scope of the framework offer does not correspond to requirements set forth in the Regulation. TP SA additionally claimed that the UKE President wrongly applied Article 22(1) and Article 21(1) PT in connection with Article 7 of the Constitution and Article 6 and 9 of the Administrative Procedure Code, as well as violated powers vested in him by the Minister of Communication. Finally, the claimant submitted that the District Court - the Competition and Consumer Protection Court infringed Article 47957(1) of the Civil Procedure Code by not overruling the decision on grounds of procedural invalidities.

\section{Key legal problems of the case}

\section{As to the obligation of proportionality and adequacy}

The first issue raised by TP SA in respect to the decision was abuse of power by the UKE President in not respecting requirements of proportionality and adequacy of an obligation imposed toward an identified aim (Article 25(4) PT). The Supreme Court recalled the origin of this provision, art. 8 of the Framework Directive. The judges found that the obligation of adequacy means that a regulatory instrument applied by a regulator by imposing specific obligations should be used to overcome or minimise existing barriers to competition on a particular market, whereas the condition of proportionality means selecting from among efficient means that could achieve a regulatory aim. This should signify minimum interference in the manner that business is conducted as well the commercial interests of an undertaking.

The Supreme Court found that in order to meet requirements of proportionality, a decision to impose a regulatory obligation must be as precise as toward the imposed obligation itself. Yet, the obligation as formulated in the decision of 'assuring every other form of use of telecom appliances and associated facilities...' is prima facie overly general since it cannot be interpreted broadly and independently from other obligations imposed on the plaintiff. The aim of this obligation is to avoid a situation in which the plaintiff blocks alternative telecommunication access to operators by refusing to provide them ancillary services. 


\section{Imposition of regulatory obligations on the retail market}

Another issue raised by the plaintiff concerned the imposition of a regulatory obligation aimed at solving problems concerning competition on the retail market. The reasoning presented by the judges states that the retail market remains directly linked to the wholesale market because the possibility of action on the latter is conditioned by suppression of specific competition barriers on the retail market, whereas the plaintiff's market position on the wholesale market is directly linked to his domination of the retail one. Therefore, regulation of the wholesale market should result in the development of competition on the retail market.

\section{Costs calculation}

Pursuant to the Article 40(1) PT, the UKE President can impose an obligation upon an operator with a significant market share to set access fees on the basis of incurred costs. According to para. 3 of this disposition, this should consider fee levels on comparable competitive markets. The plaintiff alleged that the UKE President cannot verify the fee for telecommunications access determined on the basis of methods other than the comparative method, as specified in Article 40(3) PT. Although the Court shared this argument, it found that the fact that the UKE President indicated the calculation method erroneously in the justification to the Decision does not mean that Article 40 PT was infringed. According to the Court, only after presenting the operator a fee together with its justification can the UKE President verify its accuracy through separate administrative proceedings. This would result in a decision issued on the basis of Article 40(4) PT. Only in such proceedings can the argument of erroneous method applied toward fee calculation be submitted.

\section{The scope of a framework offer}

TP SA also claimed that the UKE President erroneously applied the Regulation concerning a framework offer, because of the procedures of clearance for provision or non-provision of all services (not only as specified in the Regulation of telecommunication ones). The Court found that arrangement of an offer must be treated as specification of its scope provided that it falls within the scope indicated by the Regulation. The Court pointed out that the Regulation is very general, but differentiates separate elements of a framework offer.

\section{Infringement of authority}

According to the plaintiff, the UKE President violated exclusive authority of the Minister of Communication (hereafter, Minister) by dealing with specifications of the product side of the market in question. The Court disagreed with this argument by upholding the Appeals Court's view that the Minister indicated relevant markets 
under the Regulation, thus setting out the scope within which the UKE President can describe products and services included in a particular relevant market by checking the substitutability of demand and supply after a due analysis.

\section{Infringement of procedural rules}

The plaintiff submitted that the District Court - the Competition and Consumer Protection Court infringed Article $479^{57}(1)$ of the Civil Procedure Code by not overruling the decision. However, the Court found that no substantial basis for such a decision arose.

\section{Significance of the judgment}

The Decision was one of the first issued following the nomination of Ms. Anna Streżyńska as UKE President, thus marking a significant change of approach in regulator policy. It must be evaluated in light of the new UKE President's policy intended to break absolute dominance of the incumbent on the Polish telecoms market as well as boost competition in a relatively short term. Hence, the policy of defining the incumbent as the SMP on practically every market where possible as well as issuing framework offers on numerous services such as data (bit stream access), voice (LLU, WLR).

At the same time as the decision was issued the Regulator also delivered a decision granting the first alternative operator (Tele2 Poland) wholesale line rental (WLR). Although WLR was defined as one the obligations imposed in the decision, particular WLR decisions issued for each of the numerous alternative operators (up to eleven now) had different legal basis (transitional obligations).

A detailed analysis of the decision demonstrates that its scope is quite broad as well as vague. A first impression may be that it is incorrect, since, as TP SA claimed, legal obligations should be precise and detailed while taking into account the proportionality principle. Still, the Court's solution claiming that the Regulator may draft a decision in general terms while leaving technical implementation to concerned parties must be appreciated positively in my opinion. The telecoms industry is complex and one year is an age due to technical and economical progress. Yet, since the Regulator has been given very strong and powerful tools, as the Court emphasised, it must use them within the scope of legal powers conferred upon it and according to the proportionality principle.

The later aspect of the Decision must also be welcomed since it provides precision as to its interpretation in light of the aim of imposed obligations. There is always a plethora of detail and issues that must be settled whenever operators connect their networks in one way or another. A Regulator is practically unable to foresee and describe them all in detail in his decision and it must be welcomed that the Court noticed this fact. However, WLR is only the first rung on the investment ladder. Its aim is to give alternative operators some market strength so that they can invest in their own infrastructure in order to offer more complex services (ultimately LLU). It 
is crucial that the Regulator sets the right prices for services - the gap between WLR on the one side and LLU on the other should be left broad enough in order to push alternative operators to build their own infrastructure.

Unfortunately, this was not the case in Poland. The Regulator used different methods in setting prices of services (retail minus in case of WLR, bottom-up in case of BSA, benchmark in case of LLU) which resulted in certain inconsistencies. LLU did not work in practice in Poland until 2009. Therefore, the question remains whether the Court was right in approving the fact that the Regulator in practice granted himself broad discretion in choosing the method of defining prices of fixed call origination.

Nevertheless, for the first time, alternative operators were given a real tool for their retail offers that are similar to the incumbent (including unlimited call plans, due to PSI, also an obligation imposed in the decision). The market shares of other operators such as Netia SA and Telefonia Dialog SA is slowly growing ${ }^{3}$ although the competitive situation in the fixed market remained generally unchanged (the incumbent's market share kept essentially stable at $66.6 \%$ in terms of revenue in December 2008) which represented a decline of one percentage point ${ }^{4}$. It was no surprise that the approach of the new Regulator was not welcomed by the incumbent. Virtually all decisions delivered by the UKE President have been questioned by TP SA and at a certain point in time there were many court proceedings between the UKE President and the claimant. This only ceased at the end of 2009 when the Charter of Equivalence ${ }^{5}$ (an agreement between the Regulator, TP SA and alternative operators) was signed. This was a consequence of the threat of imposed functional separation upon TP SA. Due to the time necessary to conduct court proceedings, judicial appreciation of TP SA arguments in these decisions are delivered recently ${ }^{6}$.

\section{Matgorzata Kozak}

Assistant Lecturer at Lazarski University; a doctoral student

at the University of Toulouse I: Capitole; Lawyer in Wardyńscy and Partners law firm.

${ }^{3}$ Report of UKE, Telecommunications market in Poland in 2009, June 2010, p. 45 available at: www.uke.gov.pl.

4 15th Progress Report on the Single European Electronic Communications Market - 2009, $\operatorname{COM}(2010) 253)$ of 25 May 2010.

5 Among others, as part of the agreement, the incumbent committed to withdraw appeals relating to WLR decisions, resulting in such decisions becoming binding.

6 This issue was included in the Communication from the Commission to the European Parliament, the Council, the European Economic and Social Committee and the Committee of the Regions - Progress Report on the single European electronic communications market 2008 (14TH Report) /COM/2009/0140 final / where it was pointed out in respect to Poland that 'systematic appeals and lengthy procedures continue to undermine legal certainty and effective implementation of the framework (...)'. 